the hody as being greyish-white, or grey lead colour. In all the fresh examples I have seen, yellow enters noticeably into the colour of the ventral fur, and the almost blue colour of Waterhouse's figure is certainly never seen in this species. The dark frontal streak of Gould's drawing is intended to illustrate the convergence of the hairs to the centre of the head, but there is no colour band there as might be inferred.

\title{
ADDITIONS to THE FISH-FAUNA OF LORD HOWE ISLAND.
}

By Edgar R. Waite, F.L.S., Zoologist.

(Plates xxxv. - xxxvii.; and Figs. 1, 2).

Since 1889, when the Fish-fauna of Lord Howe Island was first published in collected form, ${ }^{*}$ sundry additions have been recorded by Mr. J. D. Ogilby and myself. The former in his latest contribution writes $\uparrow$ - "The present additions bring the number of species recorded as inhabiting or visiting the shores of the island up to one hundred and thirteen, with seven (or six) unidentified forms."

It was my intention to prepare a complete list of the known Fish-fauna of the island, but I notice that Mr. Ogilby, in 1898, also in the paper quoted, writes-"As it is, the list as it now stands needs careful revision, but I hope within the next few months to be in a position to lay before the Society a thoroughly revised and enlarged catalogue of the fish fauna of the island." Under these circumstances I will leave the field open to $\mathrm{Mr}$. Ogilby, and publish the following list of additions in order that his "revised and enlarged catalogue" may include the Museum records, not otherwise available to him.

Washed by a warm southerly current, Lord Howe Island supports a much more tropical fauna than is met with in lower latitudes on the mainland. It lies in latitude S. $31^{\circ} 33^{\prime}$, and on the west side possesses an extensive coral reef. On the mainland no coral reef is found south of Stradbroke Island in Queensland,

* Ogilby-Aust. Mus. Mem., II., 1889, Fishes, pp. 52-74.

† Ogilby-Proc. Linn. Soc. N.S.W., xxiii., 1898, p. 731. 
latitude S. $27^{\circ} 25^{\prime}$, but the fauna there is in no way comparable with that of Lord Howe Island, which is endowed with many purely tropical forms.

The temperate fishes are, in the main, those found on the coast of New South Wales, while the tropical ones generally suggest a Melanesian rather than an Australian origin.

Several bathy-pelagic fishes have already been recorded from the island; we may mention Isistius, Brama, Gempylus, and Tetragonurus. Being dependent for novelties on residents or visitors to the island, who, though kind and well meaning, can never accomplish the results of a trained collector, our work of building up a knowledge of the fauna is necessarily slow.

If a small steamer, fitted up for dredging, could be chartered for a few weeks, we should, I am confident, be able to add many new and interesting forms both among fishes and invertebrates.

The present contribution is based on material received at the Museum by the kind offices of Mrs. T. Nichols and her daughters, Mr.T.R.Icely, J.P., late Visiting Magistrate, Messrs. Wm. Nichols, and J. B. Waterhouse, residents on the island, and the late Mr. W. E. Langley.

The paper deals only with unrecorded species, two excepted, namely:-Trachinotus russelli, Cuvier and Valenciennes, and Chironemus marmoratus, Günther, previously incidentically mentioned in a publication not generally distributed.

Including an unnamed Atopichthys, thirty-ṫwo species are recorded, of which four are described as new, namely :-

\section{Amphiprion latezonatus. \\ Holacanthus conspicillatus. \\ semicinctus.}

Euchilomycterus quadradicatus.

The last-named is regarded as the type of a new genus. A new generic name, Acanthocaulus, is also proposed to replace Prionurus, Lacépède, pre-occupied. Of the remainder, the following are new to the Australian fauna; some have, however, been taken in Torres Straits:-

Leptocephalus cinereus, Rüppell.

Aulostomus chinensis, Linnæus.

Gempylus serpens, Cuvier and Valenciennes.

Decapterus sanctce-helence, Cuvier and Valenciennes.

Epinephelus fasciatus, Forskal.

Thalassoma aneitense, Günther.

Platyglossus opercularis, Günther.

Holacanthus tibicen, Cuvier and Valenciennes.

Naseus unicornis, Forskal.

Alutera monoceros, Osbeck.

Ovoides meleagris, Lacépède.

Parapercis cylindrica, Bloch. 
Those below-named, previously known from Australia, are new to the fauna of New South Wales, of which colony Lord Howe Island is a dependency :-

Isistius brasiliensis, Quoy and Gaimard.

Hippocampus hippocampus, Linnæus.

Epinephelus tauvina, Forskal.

Therapon jarbua, Forskal.

Ostracion cubicus, Linnæus.

Isistius BRAsiliensis, Quoy and Gaimard.

(Figs. 1, 2).

Under the name Leius ferox, Kner* well described this species from Australia, but without any more definite habitat. It has not been since recorded from our waters. The example now under notice was sent to the Trustees from Lord Howe Island by Mrs. T. Nicholls, and forms a most interesting addition to the fauna of the Island. In his Whaling Voyage, F. D. Bennett $\uparrow$ described, as Squalus fulgens, two examples taken at different periods of the voyage by means of a tow net, proving the pelagic habit. The largest of these was an adult female, and measured eighteen inches in length. Ours is a male, and measures $390 \mathrm{~mm}$. (= $15 \frac{1}{4}$ inches), it possesses the dark band across the chest, and the white edged fins of Scymnus torquatus, Valenciennes.

The upper teeth are arranged in thirty-three rows, in a band of crescent shape, four or five deep mesially, and two or three laterally; each tooth is strongly curved outwards and backwards, and the whole series is depressible. The palate is very hard and is evidently the counterpart of the tongue which is furnished with a similarly hard plate extending all along the front and lateral margins. Such crushing surfaces would appear to be unnecessarily developed if used only for reducing the weak shells of Ianthina and Reclusia, or even the armament of Nautilograpsus.

The lower teeth form a single functional fixed series arranged in rather more than a semicircle, with a diameter of $35.5 \mathrm{~mm}$. in the specimen examined. Each tooth consists of a thin erect plate with a triangular apex, the margins of which are smooth, the basal portion is faintly striated and has a central pit connected with the basal edge by a short channel; the median tooth is wholly exposed and bi-symmetrical (fig. 1), the lateral teeth are imbricate and their apices directed away from the symphysis, on approaching the angle of the mouth they become smaller. There are fifteen teeth on

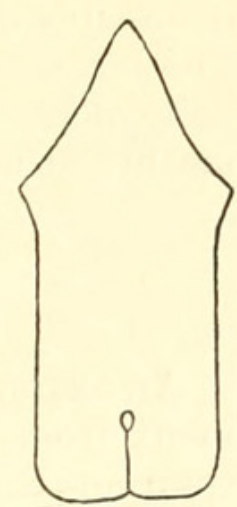

Fig. 1. each side of the median one, making thirty-one in all.

* Kner-Denks. Akad. Wiss. Wien. xxiv., 1865, p. 10, pl. iv., fig. 2.

† Bennett-Whaling Voyage, II., 1840, p. 255. 
On the inner side of the jaw there

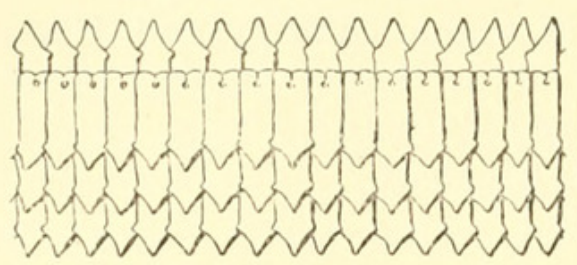

Fig. 2.

are three other rows of precisely similar teeth, apparently destined to successively replace those in use, but not functional until the existing row has been lost. When the second row of teeth has reached the summit of the alveolus, erection must be speedy, for the dentary is very thin, nowhere more than $2.5 \mathrm{~mm}$. in thickness. The teeth in reserve have their apices pointing directly downwards, and the bases of the first reserve row are applied a little above the centre of the teeth of the functional row (fig. 2).

As this paper was passing through the press the Trustees received the Report on the Deep Sea Fishes of the "Albatross"; this splendid work contains a descriptive notice and figures of Isistius. * Garman there enumerates all the examples known, from which it would appear that ours ranks as the fourteenth. The "Albatross" specimen was taken at Station 3413, where a depth of 1,360 fathoms was registered. Some idea is however expressed that the fish may have been netted during the ascent of the trawl, at a less depth.

It is of interest to notice that Garman's suggestion that the number of teeth may within certain limits increase with age, receives support from the characters of our specimen. Examples previously taken were found to have twenty-six or fewer teeth in the lower jaw, such were however, immature, being ten inches or less in length. In the individual taken by the "Albatross," which measures more than eighteen inches in length, there are thirty-one such teeth, precisely the number possessed by the Lord Howe Island specimen, as before stated. This, though not quite so large is possibly adult, as indicated by the nature of the sexual organs. The largest example recorded measures more than nineteen and a half inches in length, while Garman remarks- "The species is mature at a length of eighteen inches."

\section{Congermurena habenata, Richardson.}

An example obtained.by Mr. T. R. Icely quite agrees with specimens from the mainland, having the tail proportionately longer than in Richardson's type from New Zealand. This difference has been expressed by Ramsay and Ogilby in the name $C$. longicaudata.

\footnotetext{
lxix.

* Garman-Mem. Mus. Comp. Zool., xxiv., 1899, p. 34, pls. i., ii., iii.,
} 
ADDITIONS TO THE FISH FAUNA OF LORD HOWE ISLAND-WAITE. 197

\section{Leptocephalus cinereus, Rüppell.}

\section{Conger marginatus, Valenciennes.}

This species has been recorded from Torres Straits. The island example differs only from the descriptions in being of less uniform colouration; the ground colour is grey, crossed by about fifteen irregular more or less complete bands of a darker tint. There is a jet black spot near the tip of the pectoral, on the inner side of which it becomes a much more extensive blotch. The specimen, preserved in formol, has the colours unusually well retained.

\section{Aторichthys, Garman.}

"Heretofore certain pelagic, much compressed, band-like, translucent to transparent, larval fishes, have been placed in the genus Leptocephalus of Gronow, 1763. The type of the genus is Leptocephalus Morrisii, Penn., 1776, a larval form which has lately been traced to its adult in Muræna conger, Linn., 1758, which again was the typical species of Risso's genus Conger, 1826 . In consequence Leptocephalus has taken the place of Conger as the title of the genus, and many of the Leptocephalids which do not belong to that genus, and cannot yet be definitely located, are left unnamed. That there is a considerable number of these larval forms that cannot be placed in Leptocephalus, but that belong to various other genera not now determined with sufficient accuracy, is evident enough from the figures and descriptions given below. Rather than to assign them at random, it is here proposed to form a group for these and similar unplaced larvæ, Atopichthys, in which they may remain until such time as by means of larger collections the adult forms and their respective generic affinities may be determined."*

As this is perhaps the first occasion on which the name Atopichthys has been used since characterised, I have reprinted Garman's remarks in full.

In January last the Trustees received from the island a very fine larva, collected by Miss Nicholls. I do not propose to name this form, and will merely indicate some of its leading features :-

Body elongate, narrow and slender; greatest depth behind the middle, one-fifteenth of the entire length. Head more than twice as long as high, 13.3 in the total length. Snout pointed, nearly one-fourth of the head. Eyes lateral, 7.5 in the head, situated in its anterior half. Mouth large, reaching to below the middle of the eye. Upper jaw the longer. Teeth small, inclined backwards. Gill-opening narrower than the eye, extending below the base of the pectoral, About one hundred and fifty muscle bands.

* Garman-Loc. cit., p. 325. 
Pectoral broad, longer than the eye: no filamentary caudal. Dorsal and anal fins indistinct, better defined posteriorly. Translucent; small black spots form a band on the nape and a similar one on the throat.

$\begin{array}{ccccc}\text { Total length } \ldots & \ldots & \ldots & 200 & \mathrm{~mm} . \\ \text { Height of body ... } & \ldots & \ldots & 13 & , \\ \text { Length of head... } & \ldots & \ldots & 15 & , \\ , & \text { snout } & \ldots & \ldots & 4\end{array}$

\section{Aulostonus chinensis, Linnceus.}

Mr. T. R. Icely obtained a nice example in December, 1892. It measures $560 \mathrm{~mm}$. in length, and has the following characters :-

$$
\text { D. xii. } 25 \text {. A. } 25 \text {. P. } 16 \text {. V. } 6 \text {. C. } 15+2 \text {. }
$$

Length of head $3 \cdot 2$, height of body $11 \cdot 0$ in the total length, exclusive of caudal. Eye 3.0 in the postorbital part of the head. Lower jaw prominent, with the barbel one-half longer than the diameter of the eye. Premaxillary slender; maxillary narrow anteriorly, greatly broadened behind, its posterior margin notched. Upper jaw edentulus; lower jaw with a small patch of minute teeth in each ramus. Caudal pedicle equal in length to the distance of the posterior margin of the opercle from the centre of the eye. Ventrals short, equal to the least depth of the snout; they extend to the vent, which is situated midway between the hinder edge of the opercle and the base of the caudal rays.

When freshly obtained, the colour was pink and the fins yellow. The body is longitudinally streaked, the streaks disposed both above and below the lateral line; there is a deep black bar across the centre of the maxillary, and a narrower one passing through the nostrils to the eye; a black spot at the base of each ventral fin, and another on the upper caudal rays. The bases of the dorsal and anal fins are black, and this colour is continued up the front margin of the dorsal; the portion of the body between these fins is very dark, relieved by two of the white body streaks in a line with the upper and lower margins of the caudal pedicel, each streak with two ganglion-like spots; two similar but fainter spots exist at the bases of the fins. There are also three pairs of spots on the pedicel, forming transverse bands.

Drs. Jordan and Evermann, in describing the family Aulostomidæ, write*:- "A single genus, with two species, found in tropical seas." This should surely read "three species," for they mention $A$. maculatus and $A$. cinereus, neither of which is synonymous with $A$. chinensis, admitted as the type of the genus.

\footnotetext{
* Jordan and Evermann-Bull. U.S. Nat. Mus., 47, 1896, p. 754.
} 


\section{Macrorhamphosus gracilis, Houttyn.}

The opinion expressed by me that this species may be of more pelagic habit than $M$. scolopax, ${ }^{*}$ receives some support from the fact that an example taken on the beach at Lord Howe Island by Mr. Wm. Nichols proves to be M. gracilis.

\section{Hippocampus hippocampus, Linnoeus.}

A specimen from the island, registered under the synonym H. antiquorum, Leach, cannot, so far as I can see, be distinquished from this European species. It has been recorded from Cape York.

\section{Gempylus serpens, Cuvier and Valenciennes.}

The example now recorded was obtained per Mr. Icely in May 1893, and measures $670 \mathrm{~mm}$. in length. It differs in no way from specimens recorded from the Atlantic. Drs. Jordan and Evermann $\dagger$ describe the lateral line as being single, in our example it is certainly double, the lower line is raised above the pectoral and otherwise runs straight along the body as described; the upper one arises at the same point whence the lower one starts, namely just behind the first spine, and is continued along the dorsal profile close to the fin as far as its spinous termination. This condition was described by Cuvier and Valenciennes + in the following words"Sa ligne latérale est droite, continue et sans inflexions; il y en a comme une seconde le long de la base de la première dorsale." These authors also describe the palatines as being edentulous, and I fail to find the slightest trace of palatine teeth in our specimen; the American authors on the other hand write:-_ "palatines with a row of small teeth."

The Lord Howe Island specimen is more nearly allied to the type of $G$. serpens the Atlantic, than to G. coluber the Pacific form, a circumstance which favours the view that both are referable to the same species. It is to be inferred that the type of $G$. coluber has but one lateral line, a condition found in, presumably, Atlantic specimens by Jordan and Evermann.

In the Pacific, Gempylus has been found near the Society and Hawaiian Islands, its distribution is now therefore greatly extended westwards. "It is generally believed to be an inhabitant of great depths," in this connection I am sorry not to be able to throw more light on the subject. The Lord Howe Island example was certainly not taken in deep water, but I am not aware whether it was caught on the line or thrown upon the beach. Of the wide

* W̉aite-Aust Mus. Mem. iv., 1, 1899, p. 60.

† Jordan and Evermann-Bull. U.S. Nat. Mus., 47, 1896, p. 884.

$\ddagger$ Cuvier and Valenciennes-Hist. Nat. Poiss., viii., 1831, p. 210. 
distribution of the species there can be no doubt, and it is interesting to notice that the forms having the most extensive range are either bathybial or pelagic in habit.

\section{Decapterus sancte-Helene, Cuvier and Valenciennes.}

To this species I refer a fine example obtained by Mrs. T. Nichols last year. It measures $310 \mathrm{~mm}$. in length and though not in very good condition, exhibits all the features of the species with the exception of the character of the first dorsal spine, this is short, not half the length of the second and is correspondingly feeble. I have assumed that Steindachner is correct in regarding Caranx muroadsi, Temminck and Schlegel, as synonymous with D. sanctcehelence.

\section{Trachinotus Russelli, Cuvier and Valenciennes.}

This species is incidentally mentioned by Ogilby* as occurring at Lord Howe Island, but as the reference might easily be overlooked, attention is here drawn to it. The specimens in the Museum were received from Mr. Icely.

\section{Brama raII, Bloch.}

Castlenau has recorded this species from Port Jackson, but doubt has since been thrown upon his identification. We have an example in the Museum, obtained from Lord Howe Island by Mr. Icely, so that Castlenau's record was doubtless correct. It has the characteristically deeply forked caudal of the species, and the radial formula is D iii. 33; A. ii. 28. Like Lampris luna (a notice of which recently appeared in this publication), Brama raii is a large pelagic fish, widely distributed and descending to considerable depths; any new recorded habitat, though interesting, is therefore not surprising.

\section{Epinephelus fasciatus. Forskal.}

This species is represented from the island by a fine example, $300 \mathrm{~mm}$. in length. Previously it was known from Darnley Island in Torres Straits, which gave it a place in the Australian fauna. We have other two specimens in the collection, one of which is from Port Moresby, British New Guinea, possibly an unrecorded habitat.

\section{Therapon Jarbua, Förskal.}

This widely distributed species has been recorded from the north and north-east coast of the continent, and a single example obtained by Mr. Icely, enables me to add it to the fauna of Lord Howe Island.

* Ogilby-Edible Fishes N.S.W., 1893, p. 90. 


\section{Chironemus marmoratus, Günther.}

The Kelp-fish is common on the coast of New South Wales, and is, I learned from the Lord Howe Islanders, sometimes caught off the coral reefs. We have an example in the Museum, obtained by Mr. Icely, and this is recorded by Ogilby, ${ }^{*}$ but for reasons applied to Trachinotus, is also noticed here.

\section{Amphiprion latezonatus, $s p$. nov.}

\section{(Plate xxxiv.)}
D. xi. 15 .
A. ii. $13 . \quad$ V. i. 5 .
P. 17.
C. $15+2 . \quad$ L. lat. 38 . L. tr. $6 / 18$.

Length of head, to which the caudal fin is equal, $3 \cdot 6$, height of body $2 \cdot 0$ in the length (caudal excluded). Diameter of eye $2 \cdot 8$, length of snout 3.5 in the length of the head. Interocular space very slightly convex, a little more than the diameter of the eye. Twelve gill rakers on the lower limb of the first arch, the centre ones narrow and rather long. Teeth conical in a single series in each jaw. Preopercle denticulated, its angle in advance of the centre of the eye. Opercle formed of two lobes strongly spinose. Dorsal fin without notch, its first spine placed above the margin of the opercle, its length less than the diameter of the eye, the eighth spine is the longest, and is one-tenth longer than the eye; the central rays are the longest, twice the diameter of the eye. The anal spines are short but stout, and the longest rays are more posterior than the corresponding ones of the dorsal.

The pectoral and ventral are long and equal, one-seventh longer than the head, the latter extending to the base of the second anal spine. The caudal is forked, the upper rays the longer, the length of the pedicel equals its height, which is one half the length of the head.

Scales.-The scales are large, with entire margins, the lateral line, which terminates in advance of the dorsal rays is composed of thirty eight scales, this is also the number of the series between the opercle and the caudal.

Colours.-General colour dark brown with three light cross bands, the first is as wide as the diameter of the eye, the posterior margin of which it embraces; it passes from the occiput, in front of the dorsal spines downwards and forwards, and crosses the preopercle, opercle, and sub-opercle: its posterior margin is convex and on the dorsal profile this margin is deflected forwards. The second band arises in the space between the eighth spine and the second ray, its anterior edge takes a forward sweep gaining the ventral profile just behind the ventral fins, its hinder edge is

* Ogilby-Edible Fishes N.S.W., 1893, p. 55 . 
deflected backwards to near the termination of the anal fin along the base of which it passes to the first anal spine; this second band is thus much wider below than above, and at its widest part equals the distance of its anterior edge from the snout; it is not bent backwards along any part of the soft dorsal. The third band is across the caudal pedicel, it is wider than the first band and both edges are concave posteriorly. All the bands are separated from the ground colour by a narrow white line. The membranes of the spinous dorsal are coloured according to the tint of that part of the body whence they arise; the whole of the soft dorsal, with the exception of the base of the first two rays, is blackish-brown edged with yellow, the anal has no light margin; the pectorals are coloured like the body bands, but their bases are dusky; the ventrals are wholly dark. The caudal rays are very deep brown, which colour extends along the upper and lower rays, leaving a broad lunate margin of yellow. Length of specimen $130 \mathrm{~mm}$.

Some of the species of Amphiprion have been shown to be very variable, it is therefore not easy to say what amount of variation must be allowed. The example now under notice, enters section $b$ of Günther's synopsis* characterised by having "Three white cross bands, the middle of which is not bent backwards above." In colouration it differs from any previously described by having the middle band extremely wide, and much wider below than above, also by the margin of the brown colour of the caudal being posteriorly concave.

\section{Thalassoma aneitense, Günther.}

Julis aneitensis, Günther, Brit. Mus., Cat. Fish. iv., 1862, p. 183.

Included in a small collection made by Mr. J. B. Waterhouse is a nice example of this species, measuring $260 \mathrm{~mm}$. in length. Günther has recorded it from Norfolk Island, and it has also been recognised from North-east Australia, so that its occurrence off Lord Howe Island is in no way remarkable.

\section{Platyglossus opercularis, Günther.}

Of this species, which appears to be nearly allied to P. poecilus, Rich., we have four examples obtained by Mrs. T. Nicholls in August last. There are also specimens in the Museum from the New Hebrides.

\section{Novaculichthys Jacksoniensis, Ramsay.}

The single example obtained by Mr. Icely in January, 1895, is somewhat larger than that taken by the "Thetis" Expedition, $\uparrow$ measuring $210 \mathrm{~mm}$. in length. As in the type, the lower

* Günther-Brit. Mus. Cat. Fish., iv., 1862, p. 3.

† Waite-Aust. Mus., Mem., iv., "Thetis" Exp., 1, Fishes, 1899, p. 87, pl. xv. 
canine teeth are developed equally with the upper ones; both pairs are curved and divergent, the lower biting between the upper ones which are rather widely spaced. The second dorsal spine is united to the third, as shown in my figure.

\section{Chelmo truncatus, Kner,}

A beach-dried example was obtained by Mrs. T. Nicholls, and forwarded to us in August last; and in the "old collection" there is a specimen in spirits, also from the island.

\section{Holacanthus tibicen, Cuvier and Valenciennes.}

All the specimens received from the island possess but three anal spines, as in normal examples, and have fourteen dorsal spines. This record is an addition to the Australian fauna, and we are indebted to Mr. Icely for the series obtained.

\section{Holacanthus conspicillatus, $s p$. nov.}

(Plate $\mathrm{xxxv}$.)
D. i. + xiii. 18 .
A. iii. 18 .
V. $1 \cdot 5$.
P. 17.
C. $15+2$.

Length of head $4 \cdot 4$, of caudal fin $5 \cdot 4$, height of body $2 \cdot 0$, in the length (caudal excluded). Diameter of eye $3 \cdot 7$, length of snout $3 \cdot 2$, of the preopercular spine $2 \cdot 0$ in the length of the head. The interorbital space is convex, one-fourth more than the diameter of the eye. Thirteen gill-rakers on the lower limb of the first arch, all small, triangular in shape. The teeth are cardiform, and are arranged in a dense band across the front in each jaw. The individual tooth is brown, with a lighter apex, broader than the base; it is tricuspid, the centre cusp long and acute, the lateral ones small and slightly deflected outwards. Body somewhat elongate, anterior profile slightly concave above the snout and in front of the orbits, snout protruding, protractile, the lower jaw much the longer; maxilla nearly vertical, equal in length to the diameter of the eye; margin of preopercle inclined forwards, below feebly serrated; spine gently curved, not channeled, reaching to beneath the bony margin of the opercle, a membrane closely invests its whole inner surface; the spine is received into a shallow groove in front of the pectoral. The angle of the opercle is slightly produced, but there is no spine. There is a short recumbent spine immediately in advance of the first erect dorsal spine which arises in advance of the vertical from the opercular border; the eleventh spine is the longest 1.55 in the length of the head and is slightly shorter than the longest rays. The first anal spine arises beneath the eleventh dorsal, to which the third anal is equal, the soft dorsal and anal are not produced but are rounded posteriorly, both terminate in the same vertical line, but the anal rays extend somewhat further back, nearly to the base of the caudal. Pectoral longer than the ventral which latter is contained 
1.3 times in the length of the head and the scarcely produced outer rays reach slightly beyond the vent. . Caudal rounded, the upper lobe rather the longer, the least height of the pedicel half the length of the head.

Scales. - Head, body and all the fins densely covered with scales, those of the body as seen on the fish are deep and short, strongly ctenoid; they are so small and irregular as to render counting not possible. When removed from the body a single scale is seen to be deep seated with a comb-like margin exhibiting about fourteen teeth; in situ the scales are greatly imbricate, their pectinations alone exposed. The lateral line is to be very faintly traced, it follows the curvature of the back to between the termination of the dorsal and anal fins whence it proceeds along the middle of the caudal pedicel.

Colours.-The head is dirty yellow, (brighter in the younger example) darker on the preopercle. On the occiput the colour gradually merges into that of the body, which together with the bases of the vertical fins and the caudal pedicle is a rich coffeebrown ; the exposed portions of the jaws, the chin and chest are a darker brown. The eye is encircled by a dark line, which in life may have shown traces of blue; above, behind and below the eye this line follows the curvature of the orbit, but anteriorly is produced forwards, the upper part passing through the nostrils and finally joining the lower portion on the anterior edge of the preorbital. Another line marks the posterior edge of the preopercle, is deflected up the base of the spine and returns along its lower border to the point of origin; the opercle is also margined by a dark line and the opercular membranes are black. Anteriorly a broad submarginal band of brown arises on the membrane of the dorsal spines and passes along the whole of the fin, becoming darker posteriorly; the margin of the membrane is yellow. The whole of the anal is very dark.brown and is margined with greyish-blue. The pectorals are yellow basally, the posterior half black with a yellow margin; the ventrals are without markings. The caudal is yellow, which colour is sharply separated from the brown of the pedicel, its upper and lower margins are narrowly edged with black, and its posterior third is also black, this colour being narrow on the lobes and broadening greatly towards the middle; the rays are narrowly margined with yellow. Total length of two specimens $250 \mathrm{~mm}$. and $170 \mathrm{~mm}$. respectively.

Holacanthus semicinctus, $s p$. nov.

(Plate xxxvi.)
D. $x v, 17$.
A. iii. 18 .
V. i. 5 .
P. 17.
C. $17+4$.
L. lat. 46.

L. $\operatorname{tr} .7+22$.

Length of head $3 \cdot 85$, of caudal tin $4 \cdot 53$, height of body $2 \cdot 1$ in the length (caudal excluded). Diameter of eye $3 \cdot 6$, length of snout 
$3 \cdot 1$, of preopercular spine $2 \cdot 0$ in the length of the head ; the interorbital space is convex, one-fourth more than the diameter of the eye. Gill-rakers narrow, of moderate length, eleven on the lower limb of the first arch. The teeth are cardiform, arranged in a narrow band in each jaw, each with a tricuspid apex. The body is rather elongate, the anterior profile slightly rounded and tumid above the snout; jaws equal, only slightly protractile, the maxilla is shorter than the diameter of the eye; preorbital produced into a spine directed horizontally forwards and its lower angle into three smaller spines directed forwards and downwards, followed by four small points. Preopercle inclined forwards, its hinder limb strongly serrated, its lower with four strong denticles. The spine is gently curved and received into a shallow groove in front of the pectoral, its point reaches the vertical from the margin of the opercle, a membrane invests its inner surface. The opercle and subopercle finely denticulated the points rather distant. The first dorsal spine is situated above the opercular margin, and its length equals the diameter of the eye, the others gently increase in length to the fifteenth which is the longest, and last, exactly twice the length of the first, the central rays are produced but not filamentous, the tenth which is the longest, is three-fourths the length of the head.

The first anal spine arises beneath the eleventh dorsal, the third is the longest, 1.6 in the length of the head; all are stouter than the dorsals. The rays are similar in character and extent to those of the dorsal and it is also the tenth which forms the summit of the fin which terminates evenly with the dorsal. The pectoral is equal to the head in length, as is also the ventral but its first ray is produced, the filament reaching to the first anal spine. Caudal lunate its upper and lower rays produced into filaments, the height of the pedicel is half the length of the head.

Scales.-The scales of the body are large, the exposed portions angular in shape, strongly ciliated ; removed from the body each scale is subcircular in outline a little higher than long; the scales on the fins are very small. The lateral line rises to below the fifth dorsal spine whence it follows the curvature of the back to near the termination of the rays, it then bends abruptly downwards and runs horizontally along the caudal pedicel.

Colours.-After long immersion in spirits the general colour is yellowish, tending to brownish on the head and dorsal surface, the fins are also yellowish and immaculate, with the exceptions below mentioned. The upper half of the body is crossed with eight or nine sub-vertical lines of dark brown, they have a slight posterior inclination and anteriorly do not cross the mid line of the body, they descend lower behind but do not even there reach the ventral profile; the first distinct line arises from the base of the third dorsal spine but there is a faint trace of one in 
advance of it at the base of the first spine. On the throat is a series of large, pale brown blotches arranged alternately, the dorsal and anal fins are margined by an extremely narrow edge of dark brown and there are two small spots of this colour on the $14-15$ dorsal rays, one near the base, the other nearer the margin. On the caudal pedicel the dark bands of the body are represented by spots and on the middle caudal rays are five series forming interrupted vertical bands.

Total length of specimen $195 \mathrm{~mm}$.

The species to which our specimen is nearest allied is $H$. melanospilus, Bleeker, ${ }^{*}$ (from the sea of Amboyna) which indeed in many particulars it closely resembles. I have not access to the original description, and my conclusions are formed from Günther's epitomised description, $\dagger$ and a comparison with Bleeker's figure. $\ddagger$

In $H$. melanospilus the body bands are very close together, eighteen or nineteen in number, and are continued to the ventral surface; there is a large, round, black, white-edged spot on the thorax. and the vertical fins have small, white rings. In $H$. semicinctus the body bands are widely spaced, do not exceed nine in number, and are not continued below ; there is no prominent spot on the thorax, and the caudal is marked with dark blotches. The horizontal preorbital spine which forms a noticeable feature in our specimen is not so represented in Bleeker's illustration.

\section{Acanthocaulus, gen. nom. nov.}

This name is suggested to replace Prionurus, Lacépède, 1830, preoccupied by Ehrenberg, in Arachnida, 1829. In 1898, Jordan and Evermann instituted a genus Xesurus $\|$ to receive certain American species, some of which had been described under the name Prionurus; the authors write "This genus is close to the East Indian genus Prionurus, Lacépède, differing chiefly in the character of the caudal armature, the plates in Prionurus being small, sharper, and in greater number." Messrs. Gilbert and Starks also admit the validity of the genus by adopting it for their species Xesurus clarionis. I have therefore no choice, in pointing out that the term Prionurus is inadmissible in Ichthyology, but to propose a new name. Acanthocaulus will include P. microlepidotus, Lacépede, an Australian species, and P. scalprum, Langsdorf, from Japan, but P. maculatus, Ogilby,

* Bleeker-Act. Soc. Sci. Indo-Nederl., ii. Amboina, p. 56 (fide Günther).

+Günther-Brit. Mus. Cat. Fish., ii., 1860, p. 48.

$\ddagger$ Bleeker-Atlas Ichth., ix. pl. ccclxviii. fig. 2 .

IJ Jordan and Evermann-Rep. U.S. Com. Fish and Fisheries, 1895, p. 421, (name only); and Bull. U.S. Nat. Mus., No. 47, 1898, p. 1694 (description). 
from Port Jackson and Lord Howe Island will have to be referred to Xesurus.

\section{Xesurus maculatus, Ogilby.}

Prionurus maculatus, Ogilby, Proc. Znol. Soc. 1887, p. 395.

At separate times three examples of this species were received from the island; they were included in gatherings by Messrs. Langley and Icely. Although the type was described from a specimen taken on the coast of New South Wales, it is more than probable that the species is commoner around the island than on the shores of the mainland.

\section{Naseus unicornis, Forskal.}

Two examples have been received, one in March, 1891, from Mr. Langley, and the other in August, 1899, from Mrs. T. Nicholls. - Macleay has recorded the species from Torres Straits.

\section{Alutera monoceros, Osbeck.}

The known distribution of this species is now considerably extended, Mr. Icely having in 1894 obtained two examples from the Island. It had not been previously recognised from Australia. It has also been recently added to the known fauna of the United States by Dr. Hugh M. Smith, in reference to which Dr. D. S. Jordan publishes an interesting notice. ${ }^{*}$ He therein expresses the opinion that the example represents a species distinct from A. monoceros.

\section{Ostracion cubicus, Linnceus.}

We have received, at various times, a number of specimens from the Island. Although not recorded from Eastern Australia, this species has been taken on its northern and southern coasts.

\section{Amblyrhynchotus oblongus, Bloch.}

The only adult example I have seen from the Island was brought by Mr. Icely in 1895, but there are two small examples of older date in the collection which are possibly also referable to A. oblongus. The species was not recorded from the east coast of the mainland until 1898, when it was obtained by the Thetis Expedition.

\section{Ovoides meleagris, Lacépède.}

Tetrodon meleagris, Lacépède, Hist. Nat. Poiss., 1798, i., p. 505.

In January, 1895, Mr. Icely brought us a small "Tetrodon," which I have identified with this Polynesian species.

* D.S.J.-American Naturalist, xxxiv., 1900, p. 69. 


\section{Euchilomycterus, gen. nov.}

The single specimen, regarded as the type of a new genus, differs from the descriptions of all described species of Chilomycterus, by having the anterior dorsal and a temporal spine four-rooted. Owing to the indifferent condition of the specimen, the nature of the nasal tentacles (if present) cannot now be determined; the presence of a spine in the middle of the forehead would indicate a nearer subgeneric affinity to Cyclichthys than to Chilomycterus. As far as ascertainable, therefore, the new genus may be characterised as follows:-Body broad, compressed?. Dermal spines very short, immovable, mostly with three roots, the anterior dorsal, and a temporal spine, with four roots; all roots (excepting those of the temporal one) overlap, forming a coat of mail. Caudal practically without pedicel; fins small; jaws without median suture.

\section{Euchilomycterus quadradicatus, sp. nov.}

$$
\text { D. } 12 \text {. A. } 10 \text {. P. } 17 \text {. C. } 9 \text {. }
$$

Length of head $2 \cdot 8$, of caudal fin $3 \cdot 7$ in the total length, interocular space flat and broad, the distance between the middle supraocular spines equal to the length of the head, eyes large, lateral, not quite so long as the snout. The dorsal spines are very low, little more than tubercles: eight or nine between the eye and the tail, those on the sides and belly are scarcely larger, excepting the posterior ones which do not however attain to $3 \mathrm{~mm}$. in length; the two lateral spines behind the dorsal fin throw their inner roots together on the median line, and behind them is a pair of roots bearing a minute median spine. With this exception, and those below noticed, all the spines are three rooted, the anterior root covering the lower lateral one of the spine in advance of it. All the roots form strong butresses against the spine. Three supraorbital spines, the anterior of which sends its inner root across the forehead, and projected between them is the anterior root of a minute median spine. From this point, backwards, to between the gill openings, the spines have four roots arranged longitudinally and transversely. A four-rooted spine (the temporal) exists between the the third supraocular and the large three-rooted spine situated above the gill opening; it is of regular shape, and its roots scarcely touch those of any other spine. The coloration cannot be given, as the specimen is dry and faded. Total length $180 \mathrm{~mm}$.

I have not figured this species because its most striking features have already been sufficiently expressed and the specimen is not in suitable condition for delineation. It was forwarded to us by Mrs. Nichols in January last. Apart from the peculiarities mentioned, it seems to have some resemblance to Chilomycterus tigrinus, Cuvier. 


\section{Pterois zebra, Cuvier and Valenciennes.}

$P$. volitans proves to be quite common off the Island whence we have received many examples. The inclusion of $P$. zebra, on the other hand, rests on the evidence of a single specimen forwarded by Mr. Icely. Both species occur in Port Jackson, but, similarly, the former is much the commoner, or, as I should say, the less rare. Neither species has been recorded on the Australian Coast south of Port Jackson.

\section{Parapercis Cylindrica, Bloch.}

Scicena cylindrica, Bloch., Ichth., 1797, pl. 299, fig. 1.

We possess two examples from the Island, one obtained by Mr. Icely in 1893, and the other by Mrs. Nicholls in January last. Günther* mentions that a specimen from Aneiteum differs from others in the British Museum by having fifty-eight, instead of fifty transverse rows of scales, and by the ventral fin reaching only to the third, instead of the fifth anal ray. In both our specimens there are fifty-four scales in the lateral line; in one, the ventrals reach to the third anal ray, in the other, to the first only. In an example from the Admiralty Islands there are also fifty-four series of scales, while the ventrals reach to the fourth anal ray.

\section{Cristiceps australis, Cuvier and Valenciennes.}

Of the two species originally recorded from the Island, namely, C. aurantiacus, Cast., and C. roseus, Günth, the latter enters Ogilby's genus, Peträites. A specimen secured by Mr. Icely is to be identified with C. australis, Cuv. and Val. Port Jackson examples of which Castelnau designated C. macleayi.

* Günther-Brit. Mus. Cat. Fish, ii., 1860, pp. 239 and 525. 


\section{$2 \mathrm{BHL}$ Biodiversity Heritage Library}

Waite, Edgar R. 1900. "Additions to the fish-fauna of Lord Howe Island." Records of the Australian Museum 3, 193-209. https://doi.org/10.3853/j.0067-1975.3.1900.1171.

View This Item Online: https://www.biodiversitylibrary.org/item/31166 DOI: https://doi.org/10.3853/j.0067-1975.3.1900.1171

Permalink: https://www.biodiversitylibrary.org/partpdf/16251

\section{Holding Institution}

Harvard University, Museum of Comparative Zoology, Ernst Mayr Library

\section{Sponsored by}

Harvard University, Museum of Comparative Zoology, Ernst Mayr Library

\section{Copyright \& Reuse}

Copyright Status: NOT_IN_COPYRIGHT

This document was created from content at the Biodiversity Heritage Library, the world's largest open access digital library for biodiversity literature and archives. Visit BHL at https://www.biodiversitylibrary.org. 